\title{
Prava u sustavu socijalne skrbi u kontekstu doprinosa socijalnoj sigurnosti romske djece
}

doi: $10.3935 /$ rsp.v25i2.1549

UDK: $364.65-053.2(4=214.58)$

\section{UVOD}

Definicije i pristupi u razumijevanju koncepta socijalne sigurnosti u literaturi nisu sasvim ujednačeni. Često ovise o nacionalnom kontekstu u kojima su izgrađeni specifični sustavi socijalne sigurnosti, ali i o vrsti organizacije koja djeluje u tom području. Definicije se tako kreću od užih shvaćanja prema kojima se socijalna sigurnost poistovjećuje s konceptom socijalnog osiguranja financiranog doprinosima osiguranika do širih shvaćanja, koja u koncept socijalne sigurnosti uključuju i (1) novčana davanja financirana iz državnog proračuna putem poreza, (2) različite socijalne usluge, te (3) općenito sve javne (te ponekad i privatne) politike, instrumente, mjere i aktivnosti kojima je svrha zaštita građana od različitih socijalnih rizika i potreba, odnosno pomoć u suočavanju s ranjivošću, različitim životnim nedaćama, siromaštvom i socijalnom isključenosti (Šućur, 2003.; Crnjac Pauković, 2005.; European Comission, 2017.; UNICEF, 2015.; Šućur, Babić, Urban, Baran, 2016.). UNICEF (2015.) u svom regionalnom izvješću o socijalnoj sigurnosti djece za područje srednje $\mathrm{i}$ istočne Europe kao jednu od ključnih komponenata sustava socijalne sigurnosti ističe i mjere čija je svrha smanjenje barijera koje korisnicima onemogućavaju pristup socijalnim uslugama i ser- visima (kao npr. smanjenje diskriminacije, osiguravanje prijevoza, ukidanje naknada za korištenje usluga i sl.).

Uz skupine (dugotrajno) nezaposlenih i siromašnih, u Hrvatskoj i Europi u različitim istraživanjima posebno se ističu pripadnici romske nacionalne manjine kao društvena skupina koja iziskuje dodatne i integrirane napore u eliminiranju različitih aspekata socijalne isključenosti (uključivanje u tržište rada, pristup zdravstvenim, obrazovnim i drugim uslugama u zajednici itd.) (UNDP, 2006.). Opterećeni siromaštvom, diskriminacijom i socijalnom isključenošću, Romi se vrlo često javljaju kao građani koji dugotrajno koriste različita prava iz sustava socijalne skrbi, posebno novčane naknade ${ }^{1}$, ali se unatoč tome njihov položaj u smislu socijalne integracije i napretka vrlo sporo mijenja. Samo u Hrvatskoj stope siromaštva Roma su i do dva i pol puta veće nego ostalog stanovništva. Gotovo svi Romi (92,3\%) žive u relativnom siromaštvu, a 9\% njih (u odnosu na $5,5 \%$ ostalog stanovništva) živi u apsolutnom siromaštvu što znači da ne mogu zadovoljiti minimalne životne potrebe (Bagić i sur., 2014.). U literaturi se nailazi i na procjene da čak $70 \%$ romskih obitelji živi u ekstremnom siromaštvu (Šućur i sur., 2015.).

\footnotetext{
${ }^{1}$ Reprezentativno istraživanje kućanstva Roma pokazalo je da $74,2 \%$ od ukupnog broja ispitanika izjavljuje kako su im socijalne potpore najvažniji izvor prihoda, a samo $17,6 \%$ izjavljuje da im je najvažniji izvor formalno zaposlenje (Štambuk, 2005.). U nekim romskim naseljima postotak kućanstava ovisnih o socijalnim potporama kreće se i do $90 \%$ u kombinaciji s gotovo jednakim stopama nezaposlenosti (Vlada RH, 2012.).
} 
Začarani krug niske obrazovanosti, prostorne segregacije, nezaposlenosti i dugotrajnog, često ekstremnog siromaštva posebno pogađa romsku djecu koja su u brojnim istraživanjima prepoznata kao posebno ranjiva skupina djece (Bagić i sur., 2014.; Šćur i sur., 2015.; UNICEF, 2015., 2015.a). Romska djeca su među skupinama koja ujedno i najteže ostvaruju svoja prava koja su im, između ostalog, jamčena i Konvencijom o pravima djeteta: pravo na socijalnu sigurnost, uključujući socijalno osiguranje (čl. 26.), te pravo na životni standard primjeren njihovu tjelesnom, duševnom, duhovnom, moralnom i društvenom razvoju (čl. 27.). Sustav socijalne skrbi (odnosno, prava i usluge koje se unutar njega mogu ostvariti) ima značajnu ulogu u kontekstu osiguranja optimalnog okruže- nja za napredak i razvoj romske djece kao materijalizacije prava zajamčenih Konvencijom.

U Republici Hrvatskoj sustav socijalne skrbi uređen je dvama osnovnim zakonskim propisima koji direktno ili indirektno utječu na djecu: Zakonom o socijalnoj skrbi (NN 157/2013., 152/2014., 99/2015., 52/2016., 16/2017., 130/2017.) i Zakonom o doplatku za djecu (NN 94/2001., 138/2006., 107/2007., 37/2008., 61/2011., 112/2012., 82/2015.). I jednim i drugim zakonom regulira se ostvarivanje prava na novčane naknade čija je svrha ublažavanje rizika od siromaštva. Zakonom o socijalnoj skrbi (dalje u tekstu: ZOS) predviđeni su i različiti oblici socijalnih usluga kao dodatna socijalna potpora u okviru nematerijalnih davanja (Tablica 1).

Tablica 1.

Prava u sustavu socijalne skrbi prema Zakonu o socijalnoj skrbi

\begin{tabular}{|c|c|}
\hline NOVČANA DAVANJA & SOCIJALNE USLUGE \\
\hline $\begin{array}{l}\text { 1. Zajamčena minimalna naknada } \\
\text { 2. Naknada za troškove stanovanja } \\
\text { 3. Troškovi ogrjeva } \\
\text { 4. Naknada za osobne potrebe korisnika } \\
\text { smještaja } \\
\text { 5. Jednokratna naknada } \\
\text { 6. Naknade u vezi s obrazovanjem } \\
\quad \text { naknada za redovito studiranje } \\
\text { • naknada za troškove smještaja u } \\
\quad \text { učeničkom domu } \\
\text { naknada za troškove prijevoza } \\
\text { 7. Osobna invalidnina } \\
\text { 8. Doplatak za pomoć i njegu } \\
\text { 9. Status roditelja njegovatelja ili status } \\
\text { njegovatelja } \\
\text { 10. Naknada do zaposlenja } \\
\text { 11. Naknada za ugroženog kupca } \\
\text { energenata }\end{array}$ & $\begin{array}{l}\text { 1. Prva socijalna usluga (informiranje, } \\
\text { prepoznavanje i početna procjena potreba) } \\
\text { 2. Savjetovanje i pomaganje (pojedincu i obitelji) } \\
\text { 3. Pomoć u kući } \\
\text { 4. Psihosocijalna podrška } \\
\text { 5. Rana intervencija } \\
\text { 6. Pomoć pri uključivanju u programe odgoja i } \\
\text { redovitog obrazovanja (integracija) } \\
\text { 7. Boravak } \\
\text { 8. Smještaj } \\
\text { 9. Privremeni smještaj } \\
\quad \text { u kriznim situacijama } \\
\text { • radi provođenja kraćih } \\
\quad \text { rehabilitacijskih programa } \\
\text { smještaj djece bez odgovarajuće } \\
\text { roditeljske skrbi } \\
\text { smještaj u drugim slučajevima } \\
\text { 10. Dugotrajni smještaj } \\
\text { 11. Obiteljska medijacija } \\
\text { 12. Organizirano stanovanje }\end{array}$ \\
\hline
\end{tabular}




\section{PRAVA U SUSTAVU SOCIJALNE SKRBI IZ PERSPEKTIVE ROMSKE DJECE I ROMSKIH OBITELJI}

\section{Zajamčena minimalna naknada}

Zajamčena minimalna naknada (dalje u tekstu: ZMN) je, uz doplatak za djecu, najčešća novčana naknada koju primaju pripadnici romske nacionalne manjine budući da, uslijed visokih stopa nezaposlenosti, uglavnom niti nemaju drugih prihoda. Budući da iznos ZMN-a ovisi o ukupnom zbroju udjela pojedinih članova obitelji, moglo bi se zaključiti da se takav pristup obračunavanju iznosa ZMN-a odlikuje individualnošću i prilagodbom potrebama korisnika. No, uočava se nekoliko odredaba koje, posebno u kontekstu romskih obitelji, nisu dovoljno osjetljive za potrebe ove populacije:

- ograničenost maksimalnog iznosa ZMN-a bruto iznosom minimalne plaće u Republici Hrvatskoj (čl. 30. st. 4.) $)^{2}$ bez obzira na veličinu obitelji. Unatoč jasnoj svrsi ove odredbe (poticanje na rad i zapošljavanje), ona izravno pogađa višečlane obitelji (a romske obitelji najčešće jesu takve uslijed visoke stope nataliteta među romskom populacijom) pa se na neki način može smatrati i diskriminacijskom. Tako iznos ZMN-a za obitelj s osmero djece i dvoje odraslih (što nije rijetkost među Romima) u iznosu od 3 $520 \mathrm{kn}$ premašuje iznos minimalne bruto plaće. U zakonu nije definirano postupanje u ovakvim situacijama. Istovremeno, taj iznos nije niti približno dovoljan za osnovne potrebe deseteročlane obitelji.
- uvjetovanost ostvarivanja drugih prava u sustavu socijalne skrbi pravom na ZMN kao što je primjerice, naknada za troškove stanovanja ili troškove ogrjeva (čl. 41. st. 2. i čl. 43. st.1. ZOS-a). Tu su i neka druga prava o kojima odlučuju jedinice lokalne i/ili regionalne samouprave namijenjena djeci, a koja se često uvjetuju primitkom ZMN-a (npr. pravo na besplatne udžbenike, subvencionirani prijevoz, besplatnu školsku kuhinju i sl.). Uz to, činjenica da se određena prava priznaju samo korisnicima ZMN-a obeshrabrujuće djeluje na zaposlene, a koji npr. primaju minimalnu ili tek nešto malo višu plaću. Visina ZMN-a koju može ostvariti višečlana obitelj u takvim situacijama može biti i veća od bruto iznosa plaće zaposlene osobe te takva zakonska odredba u nepovoljan položaj stavlja obitelji gdje je jedan član zaposlen zbog čega ne može ostvarivati neka dodatna prava. Romi, kada su i zaposleni, uglavnom obavljaju niskokvalificirane i slabo plaćene poslove te u tom smislu njihov dohodak ponekad može biti i manji od korisnika ZMN-a. Takva situacija pogoduje i jačanju gospodarske aktivnosti romskog stanovništva u sivoj ekonomiji i tzv. radu na crno.

- ukidanje ZMN ako se ostvaruje pravo na porodiljnu naknadu (čl. 28. ZOS-a). Ovakva odredba stavlja u nepovoljan položaj obitelji s novorođenom djecom gdje roditelj ostvaruje pravo na porodiljnu naknadu. S obzirom na visinu porodiljne naknade $^{3}$, a temeljem odredbe čl. 28.

\footnotetext{
2 Bruto iznos minimalne plaće u Republici Hrvatskoj za 2018. g. iznosi 3 439,80 kn (Uredba Vlade RH, NN 122/2017.).

3 Iznos porodiljne naknade za majke izvan sustava rada iznosi $70 \%$ proračunske osnovice, odnosno $2328,20 \mathrm{kn}$ za 2018. g. (čl. 33. st. 1. Zakona o rodiljnim i roditeljskim potporama, NN 85/2005., 34/2011., 54/2013., 152/2014., 59/2017.; čl. 22. Zakona o izvršavanju državnog proračuna Republike Hrvatske za 2018. godinu NN 124/2017.).
} 
ZOS-a, ZMN se takvim obiteljima automatski ukida. Takva zakonska regulativa sporna je iz više razloga. Ponajprije, porodiljna naknada priznaje se kao pravo roditelja radi njege novorođenog djeteta i njegovog podizanja. Ukidanje ZMN-a uslijed ostvarivanja prava na porodiljnu naknadu dovodi do toga da se sredstva namijenjena novorođenčetu koriste za potrebe svih članova obitelji što značajno ograničava roditeljske mogućnosti da novorođenom djetetu osiguraju sve što mu treba i, kao što je već ranije istaknuto, do nemogućnosti ostvarivanja nekih drugih prava koja se priznaju korisnicima ZMN-a. Stoga se boljim zakonskim rješenjem smatra uvrštavanje porodiljne naknade na popis novčanih primanja koja se ne uračunavaju u prihode obitelji koji se uzimaju kao osnova za odlučivanje o priznavanju prava na ZMN (čl. 31. st. 1. ZOS-a).

- posjedovanje registriranog osobnog vozila (čl. 29. st.1. t. 3. ZOS-a) te čak i korištenje osobnog vozila u vlasništvu druge pravne ili fizičke osobe (čl. 29. st.1. t. 2. ZOS-a) kao osnova za ukidanje prava na ZMN nedovoljno je distinktivno $\mathrm{s}$ obzirom na moguću vrijednost osobnog vozila. Osim toga, imajući na umu prostornu segregiranost romskih naselja (Šućur, 2000; Šlezak, 2009.), automobil je vrlo često jedino sredstvo koje osigurava pristup zdravstvenim ili obrazovnim uslugama, posebno kada su u pitanju djeca. Posjedovanje osobnog automobila potencijalno može doprinijeti i socijalnoj integraciji romske djece kroz lakše sudjelovanje u izvanškolskim aktivnostima koje se nude na području općine/grada/županije. Stoga bi uvođenje granične financijske vrijednosti automobila kao isključive osnove za ostvarivanje prava na $\mathrm{ZMN}$ bilo pravednije $\mathrm{i}$ primjerenije.

\section{Socijalne usluge}

U kontekstu detektiranja korisnika socijalnih usluga koji su pripadnici romske nacionalne manjine, veliku teškoću predstavlja nerazdvajanje podataka prema nacionalnoj osnovi pa se iz izvještaja centara za socijalnu skrb, odnosno Ministarstva za demografiju, obitelj, mlade i socijalnu politiku teško zaključuje koje socijalne usluge romske obitelji i djeca najčešće koriste (odnosno koriste li ih uopće) i u kojem omjeru (http://www.mspm.hr/pristupinformacijama/statisticka-izvjesca-1765/ statisticka-izvjesca-za-2017-godinu/4505). $\mathrm{U}$ tom smislu valja istaknuti i problem nedostupnosti socijalnih usluga romskim obiteljima iz različitih razloga: neinformiranost, prometna izoliranost, nemogućnost plaćanja određenih socijalnih usluga (priuštivost), nedovoljna kulturalno-jezična prilagođenost itd. Istovremeno, prisutna je i općenita percepcija sustava socijalne skrbi kao platforme za ostvarivanje prvenstveno novčanih naknada, dok se socijalne usluge smatraju tek sporednim i često manje važnim mehanizmima socijalne potpore i zaštite.

U različitim analizama pokazuje se da su obitelji niskog socioekonomskog statusa, obitelji s većim brojem djece te obitelji u kojima su roditelji slabije obrazovani ili mlađe životne dobi posebno rizične obitelji koje trebaju dodatno osnaživanje te potporu roditeljstvu i obiteljskom menadžmentu. No, upravo je takvim obiteljima ta podrška i najmanje dostupna (Pećnik, 2013.; Vlada RH, 2014.; Šućur i sur., 2015.). Podrška roditeljstvu u romskim obiteljima je utoliko potrebnija što se kod njih različiti rizici javljaju u svojem najekstremnijem obliku: 
roditelji su često potpuno nepismeni i nije rijetkost da uopće nisu bili uključeni u bilo kakav oblik obrazovanja, česte su maloljetničke trudnoće i rani brakovi, višestruki porodi i velik broj djece su tradicionalna norma, uvjeti stanovanja ekstremno su loši i neadekvatni u kombinaciji s visokim stopama nezaposlenosti i siromaštva te višestrukom diskriminacijom $u$ različitim područjima (Brajša-Žganec i sur., 2011.; Šikić-Mićanović i sur., 2015.). Roditeljstvo je u takvim okolnostima teško i izazovno, a roditelji uglavnom nemaju potencijala, kapaciteta i znanja kako adekvatno skrbiti o djeci i odgovoriti na njihove potrebe. Osim toga, roditelji su u takvim uvjetima češće orijentirani na zadovoljavanje najnužnijih, fizičkih i egzistencijalnih potreba, a zbog dodatnog stresa i preopterećenosti financijskim brigama skloniji nasilnijim odgojnim postupcima (Šućur i sur., 2015.).

S aspekta podrške i osnaživanja roditelja Roma, socijalna usluga savjetovanja i pomaganja obitelji već i prema samoj svojoj definiciji ima velik preventivni potencijal u smislu osnaživanja roditeljskih vještina, vještina upravljanja obitelji, prevencije nasilja i zanemarivanja romske djece te povećanja njihove ukupne dobrobiti. Zakonski je regulirano da centar za socijalnu skrb rješenjem priznaje pravo na uslugu savjetovanja i pomaganja obitelji te se korisnici mogu uputiti u podružnicu centra, odnosno obiteljski centar ili u druge institucije u zajednici koje pružaju takve usluge (npr. savjetovališta, škole za roditelje itd.) (čl. 74. st. 4 i st. 5. te čl. 79. ZOS-a). Međutim, takav oblik pomoći obitelji, osim ako nije u okviru mjera obiteljsko-pravne zaštite, uglavnom nije dostupan romskim obiteljima zbog prostorne izoliranosti i financijskih razloga, a često takve usluge niti ne postoje u lokalnoj zajednici (posebno ne one koje su sadržajno, kulturološki i na druge načine prilagođene romskim obiteljima).

Problem nedostupnosti (i prije toga neinformiranosti o vrsti prava koje se može ostvariti kao i postojanju usluga u lokalnoj zajednici) posebno se odnosi i na socijalne usluge psihosocijalne podrške (čl. 83. ZOS-a) i rane intervencije (čl. 84. ZOSa). Imajući na umu poteškoće s kojima se suočavaju ostali roditelji djece s teškoćama u razvoju, u uvjetima života romske populacije skrb za dijete s teškoćama je još veći izazov. Podaci Europskog centra za prava Roma (prema Vlada RH, 2012.) ukazuju na praksu da se romsku djecu rođenu s teškoćama češće smještava u institucionalnu skrb na najmanje godinu ili dvije dana odmah nakon rođenja, pri čemu izravni razlog nije samo stanje djeteta već nemogućnost roditelja da skrbe o takvom djetetu zbog različitih razloga (neadekvatni stambeni uvjeti, nedostatno znanje, više djece u obitelji o kojima treba intenzivno skrbiti). Kada pak takvo dijete i nije izdvojeno iz obitelji, a uzimajući u obzir da usluge rane intervencije općenito nisu dovoljno raširene $\mathrm{i}$ dostupne ${ }^{4}$, romskim roditeljima preostaje eventualno ostvarivanje prava na novčane potpore za povećane potrebe njege djeteta s teškoćama (osobna invalidnina, status roditelja njegovatelja), dok socijalna potpora roditeljstvu u takvim slučajevima najčešće potpuno izostaje.

\section{Doplatak za djecu}

Pravo na doplatak za djecu, osim uz uvjet da živi s djetetom, roditelj stječe pod uvjetom da mu ukupni dohodak ostvaren u prethodnoj kalendarskoj godini po članu kućanstva mjesečno ne prelazi $\mathbf{5 0 \%}$ proračunske osnovice (za 2018. g. to iznosi

\footnotetext{
4 Više u Izvješću o radu Pravobraniteljice za djecu 2015. i 2016. te Nacionalnoj strategiji za prava djece u Republici Hrvatskoj za razdoblje od 2014. do 2020. godine (Vlada RH, 2014.).
} 
$1663,00 \mathrm{kn}$ ). Unutar kategorije onih koji ostvaruju pravo na doplatak za djecu formiraju se cenzusne grupe, odnosno razredi te se ovisno o tome kojoj cenzusnoj grupi kućanstvo pripada određuje iznos doplatka za djecu (tablica 2.).

Tablica 2.

Dohodovni cenzus i iznos doplatka za djecu

\begin{tabular}{l|l|l}
\hline $\begin{array}{c}\text { CENZUSNA } \\
\text { GRUPA }\end{array}$ & \multicolumn{1}{|c}{ DOHODOVNI CENZUS } & \multicolumn{1}{|c}{$\begin{array}{c}\text { IZNOS DOPLATKA ZA } \\
\text { DJECU (PO DJETETU) }\end{array}$} \\
\hline PRVA & $\begin{array}{l}\text { Prosječni mjesečni dohodak po članu } \\
\text { kućanstva ne prelazi 16,33\% proračunske } \\
\text { osnovice }(543,14 \mathrm{kn})\end{array}$ & $\begin{array}{l}9 \% \text { proračunske osnovice } \\
(299,34 \mathrm{kn})\end{array}$ \\
\hline \multirow{2}{*}{ DRUGA } & $\begin{array}{l}\text { Prosječni mjesečni dohodak po članu } \\
\text { kućanstva između 16,33\% i 33,66\% } \\
\text { proračunske osnovice (tj. od 543,14 kn do 1 } \\
\text { 119,53 kn) }\end{array}$ & $\begin{array}{l}7,5 \% \text { proračunske osnovice } \\
(249,45 \mathrm{kn})\end{array}$ \\
\hline \multirow{2}{*}{ TREĆA } & $\begin{array}{l}\text { Prosječni mjesečni dohodak po članu } \\
\text { kućanstva između 33,66\% i 50\% proračunske } \\
\text { osnovice (tj. od 1 119,53 kn do 1 663,00 kn) }\end{array}$ & $\begin{array}{l}6 \% \text { proračunske osnovice } \\
(199,56 \mathrm{kn})\end{array}$ \\
\hline
\end{tabular}

Uzmimo primjer romske obitelji s šestero djece. U slučaju nezaposlenosti oba roditelja, mjesečni iznos $\mathrm{ZMN}$-a za obitelj iznosi 2 880,00 kn. Po članu kućanstva to iznosi $360 \mathrm{kn}$. S obzirom da nemaju drugih prihoda, ova obitelj ulazi u prvu cenzusnu grupu i ostvaruje doplatak za djecu u iznosu od 299,34 kn po djetetu (dakle ukupno 1 796,04). Dodaje li se tome dodatak od $500 \mathrm{kn}$ za treće i četvrto dijete (čl. 18. Zakona o doplatku za djecu, NN 94/2001., 138/2006., 107/2007., 37/2008., 61/2011., 112/2012., 82/2015.), ukupni iznos doplatka za djecu za svu djecu u obitelji iznosi 2 $796,04 \mathrm{kn}$. Ukupan dohodak u obitelji tada iznosi 5 676,04 kn (709,50 kn po članu obitelji). Unatoč raširenoj predodžbi javnosti o visokim naknadama koje primaju Romi, dovoljno je ove iznose usporediti s iznosom od 4 491,91 kn koji predstavlja prag siromaštva za četveročlanu obitelj (DZS, 2017.).

Dodatnu poteškoću u ostvarivanju prava na doplatak za djecu (kao i prilikom pristupa drugim pravima i uslugama) predstavlja činjenica da oko $10 \%$ Roma u Hrvatskoj nema hrvatsko državljanstvo, a 3\% njih nema nikakve dokumente o državljanstvu ili druge dokumente kojima se dokazuje status (UNDP, prema Vlada RH, 2014.), što je često glavni razlog nemogućnosti pristupa osnovnim pravima. Ovakva situacija direktno utječe na romsku djecu, budući da njihovi roditelji u ovim slučajevima ne mogu ostvariti pravo na doplatak za djecu niti druge oblike socijalne zaštite.

\section{ZAKLJUČAK}

U kontekstu opće percepcije javnosti o pretjeranim pravima koja se dodjeljuju pripadnicima romske nacionalne manjine važno je razumjeti da diskriminacija nije samo nejednako postupanje prema jednakima, već i jednako postupanje prema nejednakima (Potočnjak i Grgić, 2014.). Kako je marginalan status romske zajednice u Hrvatskoj neupitan, čini se opravdanim i potrebnim poduzimanje dodatnih mjera usmjerenih i kreiranih upravo za po- 
trebe romske populacije. Za takvo stajalište postoji utemeljenje i u europskim pravnim izvorima poput Direktive o rasnoj jednakosti 2000/43/EZ (Šimonović Einwalter, 2014.). U Republici Hrvatskoj ne postoje posebni zakonski propisi koji su specifično usmjereni na Rome, već su donesene samo nacionalne strategije koje su usmjerene isključivo na romsku zajednicu $(\mathrm{Na}$ cionalna strategija za uključivanje Roma 2013.-2020.) ili su u njima prepoznate kao skupine koje zahtijevaju posebnu pažnju (Nacionalna strategija borbe protiv siromaštva i socijalne isključenosti u Republici Hrvatskoj 2014.-2020.). Kada su u pitanju djeca romske nacionalne manjine, značajno za unapređenje njihovog položaja jest to što su ona prepoznata kao posebno ranjiva skupina i u Nacionalnoj strategiji za prava djece u Republici Hrvatskoj za razdoblje od 2014. do 2020, ali i u izvješćima i aktivnostima Pravobraniteljice za djecu te se unutar tih dokumenata predlažu i mjere, odnosno postavljaju ciljevi koji se odnose isključivo na romsku djecu.

Analizom sustava socijalne skrbi učinjenom $u$ ovom radu stječe se dojam o dovoljno širokoj lepezi postojećih socijalnih prava u odnosu na novčane naknade i socijalne usluge te se $\mathrm{u}$ tom smislu donosi zaključak da nije potrebno povećavati broj postojećih socijalnih prava. No, prava koja su trenutno zakonski predviđena imaju prostora za daljnje prilagodbe s ciljem uspješnijeg odgovaranja na potrebe i specifičnosti romske populacije.

Podatke u statističkim i drugim izvješćima potrebno je voditi odvojeno prema osnovi romske nacionalnosti. Iako bi se takva praksa mogla smatrati diskriminirajućom, njezin bi cilj bio isključivo kreiranje politike i mjera koje će omogućiti bolji pristup, prilagođen specifičnostima romske populacije, i time osigurati veću razinu socijalne potpore. Sadašnja situacija ne daje realan uvid u stvarno stanje konzumiranja različi- tih prava. Posebno se to odnosi na socijalne usluge za koje je realno pretpostaviti da se u romskoj populaciji vrlo rijetko koriste. Po pitanju socijalnih usluga, za početak je potrebno raditi i na promjeni percepcije korisnika o njihovoj manjoj važnosti u odnosu na novčana davanja. Socijalne usluge za romsku populaciju imaju izrazit potencijal i trebaju se sagledavati kao ravnopravne i komplementarne novčanim potporama. U tom smislu, od presudnog je značaja učiniti ih dostupnima romskim obiteljima i djeci, ne samo fizički već i sadržajno. To bi značilo smjestiti socijalne usluge (usluge savjetovanja i pomaganja obitelji, rane intervencije i psihosocijalne podrške) u romska naselja ili u njihovu neposrednu blizinu i kao obaveznu komponentu uključiti redovite obilaske obitelji (po uzoru na mjere iz obiteljsko-pravne zaštite). Uz to, sadržajna prilagodba znači i kreiranje specifičnih, kulturalno i jezično prilagođenih programa koji će osnažiti roditelje u njihovim roditeljskim kompetencijama ali i životnim vještinama poput brige za domaćinstvo, planiranja obitelji i, posebno, upravljanja financijama jer bi se time direktno utjecalo na njihove sposobnosti racionalnijeg korištenja novčanih naknada (imajući na umu česte prigovore o nenamjenskom trošenju sredstava). Osim potpore obitelji, odnosno roditeljstvu, potrebni su i specifični, intenzivni programi za djecu s ciljem prevencije nasilja, razvoja životnih i socijalnih vještina, lakšeg uključivanja u odgojno-obrazovni sustav i integracije općenito. To sve svakako zahtijeva dodatna financijska ulaganja, ali i dodatne ljudske resurse (prvenstveno povećanje broja socijalnih radnika zaduženih isključivo za pojedino romsko naselje te dodatni aktivizam nevladinih organizacija u romskim naseljima).

Novčana davanja pak zahtijevaju neke izmjene u zakonskoj regulaciji temeljem promišljanja učinka pojedinih restriktivnih odredbi na status romskih kućanstava, 
posebno djece. Svakako su potrebne češće kontrole o načinu trošenja i restriktivnije mjere u slučajevima kada se ustanovi da se sredstva nenamjenski troše ${ }^{5}$, no ono što se nikako ne bi smjelo zakonski omogućiti jest potpuno ukidanje prava na ZMN kao način sankcioniranja roditelja uslijed nenamjenskog trošenja jer se na taj način izravno ugrožava osnovna sigurnost i dobrobit djece u tim obiteljima. Zajamčenu minimalnu naknadu potrebno je primjerenije regulirati i u odnosu na neke odredbe kao što su uvjetovanost ostvarivanja drugih prava u sustavu socijalne skrbi korištenjem prava na zajamčenu minimalnu naknadu, ukidanje $\mathrm{ZMN}$-a uslijed ostvarivanja prava na porodiljnu naknadu te posjedovanje registriranog osobnog vozila bez obzira na njegovu vrijednost kao ograničavajućeg čimbenika za ostvarivanje prava na ZMN.

\section{LITERATURA}

Bagić, D., Burić, I., Dobrotić, I., Potočnik, D., \& Zrinščak, S. (2014). Romska svakodnevica u Hrvatskoj: prepreke i mogućnosti za promje$n u$. Zagreb: UNDP, UNICEF i UNHCR u Hrvatskoj.

Brajša-Žganec, A., Franc, R., Merkaš, M. Radačić, I., Šerić, M., \& Šikić-Mićanović, L. (2011). Analiza stanja prava djece $i$ žena u Hrvatskoj. Zagreb: Ured UNICEFa- za Hrvatsku.

Crnjac Pauković, V. (2005). Europski zakonik o socijalnoj sigurnosti i najniži standardi mirovinskog osiguranja. Mirovinsko osiguranje, (12), 65-78. Dostupno na http://www.mirovinsko.hr/UserDocsImages/publikacije/revija/12/ clanci65-78.pdf

Državni zavod za statistiku Republike Hrvatske. (2017). Pokazatelji siromaštva $i$ socijalne isključenosti u 2016.- konačni rezultati. Priopćenje br.
14.1.1. Dostupno na https://www.dzs.hr/Hrv Eng/publication/2017/14-01-01_01_2017.htm

European Commission. (2017). Concept Paper $N^{\circ}$ 5: Indicators to measure Social Protection Performance. Directorate-General for International Cooperation and Development, European Commission. Dostupno na https://europa.eu/ capacity4dev/t-and-m-series/document/ indicators-measure-social-protection-performance

Pećnik, N. (2013). Kako roditelji i zajednice brinu o djeci najmlađe dobi u Hrvatskoj. Zagreb: Ured UNICEF-a za Hrvatsku.

Potočnjak, Ž., \& Grgić, A. (2014). Osnovni pojmovi i koncepcije o zabrani diskriminacije $\mathrm{u}$ radnom pravu. U Ž. Potočnjak, I. Grgurev \& A. Grgić (ur.), Perspektive antidiskriminacijskog prava (str. 1-47). Zagreb: Pravni fakultet Sveučilišta u Zagrebu.

Pravobranitelj za djecu Republike Hrvatske. (2016). Izvješće o radu pravobraniteljice za djecu za 2015. godinu. Dostupno na http:// www.dijete.hr/www/?page_id $=6243$

Pravobranitelj za djecu Republike Hrvatske. (2017). Izvješće o radu pravobraniteljice za djecu za 2016. godinu. Dostupno na http:// www.dijete.hr/www/?page id $=6243$

Šimonović Einwalter, T. (2014). Pravo EU u borbi protiv diskriminacije Roma: kojim putem naprijed?. U Ž. Potočnjak, I. Grgurev \& A. Grgić (ur.), Perspektive antidiskriminacijskog prava (str. 237-265). Zagreb: Pravni fakultet Sveučilišta u Zagrebu.

Šikić-Mićanović, L., Ivatts, A. R., Vojak, D., \& Geiger-Zeman, M. (2015). Socijalno uključivanje djece Roma (RECI+). Izvještaj za Hrvatsku. Zagreb: Pučko otvoreno učilište Korak po korak.

Štambuk, M. (2005). Obilježja romskih obiteljikućanstava. U M. Štambuk (ur.), Kako žive hrvatski Romi (str. 93-109). Zagreb: Institut društvenih znanosti Ivo Pilar.

Šućur, Z. (2000). Romi kao marginalna skupina. Društvena istraživanja, 9(2-3), 211-227. https://hrcak.srce.hr/20263

\footnotetext{
5 Iz prakse je poznato da se sredstva nenamjenski najčešće troše na alkoholna pića, cigarete i, u posljednje vrijeme, na droge koje su sve više dostupne u romskim naseljima. Posebno veliki i raširen problem predstavlja i zaduživanje kod tzv. kamatara što velik broj obitelji baca u dužničko ropstvo. Sve to dovodi do toga da djeca u konačnici ne ostvaruju korist od socijalnih transfera koji su namijenjeni njihovom uzdržavanju, školovanju i odgoju.
} 
Šućur, Z. (2003). Razvoj socijalne pomoći i socijalne skrbi u Hrvatskoj nakon Drugoga svjetskog rata. Revija za socijalnu politiku, 10(1), 1-22. https://doi.org/10.3935/rsp.v10i1.137

Šućur, Z., Kletečki Radović, M., Družić Ljubotina, O., \& Babić, Z. (2015). Siromaštvo i dobrobit djece predškolske dobi u Republici Hrvatskoj. Zagreb: Ured UNICEF-a za Hrvatsku.

Šućur, Z., Babić, Z., Urban, I., \& Baran, J. (2016). Struktura naknada, izdaci i korisnici programa socijalne zaštite u Republici Hrvatskoj: izvješće u sklopu projekta ,,Sinergijski socijalni sustav". Zagreb: Ministarstvo socijalne politike i mladih.

Šlezak, H. (2009). Prostorna segregacija romskog stanovništva u Međimurskoj županiji. Hrvatski geografski glasnik, 71(2), 65- 81. https:// doi.org/10.21861/hgg.2009.71.02.04

United Nations Children's Fund. (2015a). Social monitor: Social protection for child rights and well-being in Central and Eastern Europe, the Caucasus and Central Asia. Geneva: UNICEF. Available at https://www.unicef.org/eca/ reports/social-monitor-regional-report

United Nations Children's Fund. (2015b). The Rights of Roma Children and Women in Bosnia and Herzegovina, the former Yugoslav Republic of Macedonia, and Serbia: A comparative review and further analysis of findings from MICS surveys in Roma settlements in the three countries. Geneva: UNICEF. Available at https://www.unicef.org/eca/reports/rightsroma-children-and-women

United Nations Development Programme Hrvatska. (2006). Siromaštvo, nezaposlenost i socijalna isključenost. Zagreb: UNDP Hrvatska. Dostupno na https://esociologyveraintroduction.wikispaces.com/file/view/Siromastvo, + n ezaposlenost $+\mathrm{i}+$ socijalna + iskljucenost.pdf

Vlada Republike Hrvatske. (2012). Nacionalna strategija za uključivanje Roma, za razdoblje 2013-2020. Zagreb: Vlada Republike Hrvatske

Vlada Republike Hrvatske. (2014). Nacionalna strategija za prava djece u Republici Hrvatskoj za razdoblje od 2014. do 2020. godine.
Dostupno na https://vlada.gov.hr/pristupinformacijama/programi-strategije-planovii-izvjesca/strateski-dokumenti-vlade-rh/ ministarstvo-za-demografiju-obitelj-mlade-isocijalnu-politiku/17700

\section{PRAVNI IZVORI}

Odluka o osnovici za izračun iznosa zajamčene minimalne naknade. Narodne novine, br. $114 / 2014$.

Ujedinjeni narodi. (1989). Konvencija o pravima djeteta.

Uredba o visini minimalne plaće. Narodne novine, br. $122 / 2017$.

Vijeće Europske unije. (2000). Direktiva o rasnoj jednakosti 2000/43/EZ. Brisel: Europska unija. Dostupno na https://eur-lex.europa.eu/ legal-content/HR/TXT/PDF/?uri=CELEX: 32000L 0043\& from $=\mathrm{HR}$

Zakon o doplatku za djecu. Narodne novine, br. 94/2001, 138/2006, 107/2007, 37/2008, $61 / 2011,112 / 2012,82 / 2015$.

Zakon o izvršavanju državnog proračuna Republike Hrvatske za 2018. godinu. Narodne novine, br. $124 / 2017$.

Zakon o rodiljnim i roditeljskim potporama. $\mathrm{Na}$ rodne novine, br. 85/2005, 34/2011, 54/2013, 152/2014, 59/2017.

Zakon o socijalnoj skrbi. Narodne novine, br. 57/2013, 152/2014, 99/2015, 52/2016, $16 / 2017,130 / 2017$.

Zakon o suzbijanju diskriminacije. Narodne novine, br. 85/2008, 112/2012.

\section{MREŽNI IZVORI}

Ministarstvo za demografiju, obitelj, mlade i socijalnu politiku. (2018). Statistička izvješća [datoteka s podacima]. Dostupno na http:// www.mspm.hr/pristup-informacijama/statisticka-izvjesca-1765/statisticka-izvjesca-za2017-godinu/4505

Priredila: Maja Kutnjak Vrtarić 